REGARDS

SUR L'ECONOMIE ALLEMANDE

BULLETIN ECONOMIQUE DU CIRAC

\section{Regards sur l'économie allemande}

Bulletin économique du CIRAC

$93 \mid 2009$

Varia

\title{
Fret ferroviaire
}

DABLANC Laetitia (ed), Quel fret ferroviaire local ? Réalités françaises, éclairages allemands

\section{(2) OpenEdition}

Journals

Édition électronique

URL : http://journals.openedition.org/rea/3923

DOI : $10.4000 /$ rea.3923

ISBN : 978-2-8218-0882-9

ISSN : 1965-0787

Éditeur

CIRAC

Édition imprimée

Date de publication : 1 octobre 2009

ISSN : 1156-8992

Référence électronique

«Fret ferroviaire », Regards sur l'économie allemande [En ligne], 93 | octobre 2009, mis en ligne le 15 octobre 2009, consulté le 22 septembre 2020. URL : http://journals.openedition.org/rea/3923 ; DOI : https://doi.org/10.4000/rea.3923

Ce document a été généré automatiquement le 22 septembre 2020

(C) CIRAC 


\title{
Fret ferroviaire
}

\author{
DABLANC Laetitia (ed), Quel fret ferroviaire local ? Réalités françaises,
} éclairages allemands

\section{RÉFÉRENCE}

DABLANC Laetitia (ed), Quel fret ferroviaire local ? Réalités françaises, éclairages

allemands, Transports Recherche Innovation, La Documentation française, Paris, 2009, $235 \mathrm{p}$.

1 Cet ouvrage vient clore le projet "shortlines", dessertes locales de fret ferroviaire: perspectives économiques, environnementales et territoriales, mené sur la période 2005-2008 par une équipe d'universitaires français et allemands, et soutenu par l'ADEME dans le cadre du programme interministériel de soutien à la recherche et à l'innovation dans les transports terrestres (Predit). Si la RFA a opté pour la libéralisation de son fret ferroviaire dès les années 1993-1995 de sorte qu'aujourd'hui, plus de 300 entreprises du secteur opèrent sur son territoire, le processus s'est accéléré ces dernières années de ce côté-ci du Rhin, avec l'achèvement de la libéralisation du marché du fret ferroviaire, l'accélération des restructurations dans ce domaine d'activité au sein de la SNCF et l'apparition du concept d'opérateur ferroviaire de proximité, le tout sur fond de Grenelle environnemental. A la lumière de l'exemple américain, les auteurs s'interrogent plus particulièrement sur la pertinence de services ferroviaires de courte distance pour le transport de marchandises, évaluant en outre l'intérêt énergétique et environnemental des dessertes "shortlines» dans l'objectif d'informer décideurs politiques, élus régionaux et responsables d'entreprise. (sh) 